\title{
ANALISIS BIAYA OPERASI KENDARAAN (BOK) SEPEDA MOTOR ELEKTRIK DAN PERAHU MOTOR DALAM PERKEMBANGAN EKONOMI PEMBANGUNAN DI KABUPATEN ASMAT
}

\author{
oleh : \\ Wiryawan Purboyo \\ Asosiasi Keselamatan Kesehatan Kerja Dan Lingkungan (AK3L) Pusat \\ Email : wiryawan.punkq@gmail.com
}

\begin{abstract}
Abstrak : Kabupaten Asmat, berada pada dataran rawa, dipengaruhi oleh pasang surut air sungai. Konstruksi jalan dari hasil kajian teknis, adalah jalan melayang $\pm 2 \mathrm{~m}$ di atas permukaan tanah dasar. Permukaan jalan berupa slab papan kayu atau slab beton, didukung kolom kayu atau beton bertulang dan didirikan di atas struktur fondasi tiang pancang. Jalan direncanakan melayani beban lalu lintas ringan, yakni sepeda motor elektrik, sepeda motor roda 3, dan gerobak barang. Tujuan analisis manfaat ekonomi untuk menaksir kelayakan proyek dari aspek ekonomi, untuk itu dilakukan analisis manfaat ekonomi pada ruas jalan di Distrik Agats yang menggunakan slab beton lebar $4 \mathrm{~m}$, panjang $3 \mathrm{~km}$. Penghematan BOK dengan membandingkan BOK with project dengan BOK without project. Setelah dibangun jalan, perjalanan dari asal ke tujuan dapat menggunakan sepeda motor elektrik, yang sebelumnya menggunakan perahu motor. Dalam penelitian ini dikembangkan BOK sepeda motor elektrik dan BOK perahu motor. Metodologi dalam menganalisis parameter-parameter kelayakan, yaitu: NPV, BCR, dan IRR. Dari hasil perhitungan: BOK 1 unit sepeda motor elektrik per tahun = Rp. 19.470.000,- dan BOK perahu motor pertahun= Rp. 32.400.000,- Nilai penghematan BOK berdasarkan umur rencana selama 23 tahun=Rp.252.809.551.559,- Biaya Kontrak dan pemeliharaan= Rp.113,419,883,758,-; BCR=2,01; NPV=Rp.23.015.691.841; IRR=10,61,31\%.
\end{abstract}

Kata kunci: BOK Sepeda Motor Elektrik, BOK Perahu Motor, Konstruksi Jalan Layang, Manfaat Ekonomi

\begin{abstract}
Asmat Regency, located on a marshland, is affected by tidal river water. Road construction from the results of technical studies, is an elevated road $\pm 2 \mathrm{~m}$ above the ground level. The road surface is in the form of a wooden slab or a concrete slab, supported by wooden columns or reinforced concrete, and is erected on a pile foundation structure. The road is planned to serve light traffic loads, namely electric motorbikes, 3wheels motorbikes, and goods carts. The purpose of the analysis of economic benefits is to estimate the feasibility of the project from an economic aspect, for this reason an analysis of economic benefits was carried out on the road in the Agats District using a concrete slab $4 \mathrm{~m}$ wide and $3 \mathrm{~km}$ long. VOC savings by comparing VOC with project with VOC without project. After the road is built, the journey from origin to destination can use an electric motorcycle, which previously used a motorboat. In this study VOC developed an electric motorcycle and VOC motorboat. Methodology in analyzing feasibility parameters, namely: NPV, BCR, and IRR. From the calculation: VOC 1 unit of electric motorcycle per year $=R p .19,470,000$, - and VOC motorboats per year $=R p .32,400,000,-$ VOC savings value based on the planned life for 23 years $=R p .252,809,551,559,-$ Contract and maintenance costs $=R p .113,419,883,758,-; \quad B C R=2,01 ; \quad N P V=R p .23 .015 .691 .841$; IRR $=10,61,31 \%$.
\end{abstract}

Keywords: Electric Motorbike VOC (Vehicle Operational Cost), Motorboat VOC, Elevated Road Construction, Economic Benefit 


\section{Pendahuluan}

Penilaian Ekonomi telah lama dikembangkan memperhatikan dengan menilai kaitan antara perubahan di sektor transportasi dan dan pola pengembangan ekonomi di daerah yang dilayani (Kenneth J. Button 1993). Prasarana jalan dan jembatan merupakan salah satu bagian penting dalam mendorong pertumbuhan ekonomi pengembangan wilayah baik secara regional maupun nasional. Prasarana dan sarana yang dibangun masih dirasakan belum dapat memenuhi kebutuhan minimum masyarakat, terutama yang ada pada daerah terpencil dan pedalaman. Salah satu wilayah yang sulit untuk pengembangan infrastruktur yaitu Kabupaten Asmat karena lokasi geografis berupa rawa dan hutan serta lokasinya pada saat ini masih terpencil karena masih minim akses transportasi yang tersedia.

Pada tahap awal, infrastruktur jalan dan jembatan mampu membuka keterisolasian daerah untuk mendukung pertumbuhan. Pada tahap selanjutnya infrastruktur jalan dan jembatan dibutuhkan untuk melayani tuntutan akibat pergerakan pertumbuhan ekonomi di wilayah tersebut. Selain itu, jalan dan jembatan juga berperan penting dalam membentuk dan memperkukuh kesatuan nasional untuk memantapkan pertahanan dan keamanan nasional. Rencana pembangunan jalan Kabupaten Asmat, keseluruhannya merupakan jalan lingkungan yang berada pada dataran rawa, dipengaruhi oleh pasang surut air sungai.

Pilihan konstruksi jalan hasil kajian teknis yang akan dibangun, adalah konstruksi jalan layang $\pm 2 \mathrm{~m}$ di atas permukaan tanah dasar, dengan lebar ruang milik jalan kecil 11 meter, sesuai Peraturan Pemerintah No. 34 Tahun 34 Tentang Jalan. Permukaan jalan berupa slab papan kayu atau slab beton, didukung kolom kayu atau beton bertulang dan didirikan di atas struktur fondasi tiang pancang. Konstruksi jalan, direncanakan untuk melayani beban lalu lintas ringan, yakni sepeda motor elektrik, sepeda motor roda 3, dan gerobak barang.

Jumlah kendaraan berupa motor elektrik, speedboat, dan gerobak untuk masingmasing distrik berdasarkan Dinas Perhubungan Kabupaten Asmat, 2018 disajikan dalam Tabel 1. Prediksi kepemilikan sepeda motor litrik di Distrik Agats Kabupaten Asmat hingga tahun 2018 adalah:

1. 2016 sebesar 1.495 unit;

2. 2017 sebesar 1.575 unit;

3. 2018 sebesar 1.750 unit; dan

4. 2019 sebesar 1.945 unit.

Prediksi pergerakan lalulintas dari tahun 2019 hingga tahun 2042 (selama 23 tahun) ditunjukkan dalam Tabel 2.

Tabel 1. Jumlah Motor Elektrik, Speedboat, dan Gerobak pada 7 Distrik di Kabupaten Asmat, 2016

\begin{tabular}{|c|l|l|l|l|}
\hline No. & Distrik & $\begin{array}{l}\text { S.Motor } \\
\text { Elektrik }\end{array}$ & Speedboat & Gerobak \\
\hline 1 & Agats & 1.495 & - & 107 \\
\hline 2 & Sawaerma & 7 & 15 & 12 \\
\hline 3 & Atsy & 47 & 35 & 40 \\
\hline 4 & Fayit & - & - & - \\
\hline 5 & $\begin{array}{l}\text { Pantai } \\
\text { Kasuari }\end{array}$ & - & - & - \\
\hline 6 & Ayip & - & - & - \\
\hline 7 & Kamur & - & - & - \\
\hline Jumlah Total & 1.549 & 50 & 159 \\
\hline
\end{tabular}

Sumber: Dinas Perhubungan Kabupaten Asmat, 2018

Tabel 2. Prediksi Jumlah Kendaraan di Distrik Agats Kabupaten Asmat tahun 2019 hingga 2042 (selama 23 tahun)

\begin{tabular}{|c|c|c|c|}
\hline No. & Tahun & LHR & Keterangan \\
\hline 1 & 2019 & 567,940 & \\
\hline 2 & 2020 & 584,978 & \\
\hline 3 & 2021 & 602,528 & \\
\hline 4 & 2022 & 620,603 & \\
\hline 5 & 2023 & 639,221 & \\
\hline
\end{tabular}




\begin{tabular}{|c|c|c|c|}
\hline No. & Tahun & LHR & Keterangan \\
\hline 6 & 2024 & 658,398 & \\
\hline 7 & 2025 & 678,150 & \\
\hline 8 & 2026 & 698,495 & \\
\hline 9 & 2027 & 719,449 & \\
\hline 10 & 2028 & 741,033 & \\
\hline 11 & 2029 & 763,264 & \\
\hline 12 & 2030 & 786,162 & \\
\hline 13 & 2031 & 809,747 & \\
\hline 14 & 2032 & 834,039 & \\
\hline 15 & 2033 & 859,060 & \\
\hline 16 & 2034 & 884,832 & \\
\hline 17 & 2035 & 911,377 & \\
\hline 18 & 2036 & 938,718 & \\
\hline 19 & 2037 & 966,880 & \\
\hline 20 & 2038 & 995,886 & \\
\hline 21 & 2039 & $1,025,763$ & \\
\hline 22 & 2040 & $1,056,536$ & \\
\hline 23 & 2041 & $1,088,232$ & \\
\hline 24 & 2042 & $1,120,879$ & \\
\hline & & & \\
\hline
\end{tabular}

\section{BOK Sepeda Motor Elektrik dan BOK Perahu Motor}

Di daerah studi yaitu di Distrik Agats Kabupaten Asmat mempunyai kekhususan dibandingkan dengan daerah lain yaitu mayoritas penggunaan Sepeda Motor Elektrik sebagai alat transportasi pada jalan layang yang dibangun, sedangkan untuk daerah yang belum dibangun jalan digunakan perahu motor. Sehingga pada tahap awal perhitungan, yaitu penghematan Biaya Operasi Kendaraan (BOK) diperlukan pengembangan BOK Sepeda Motor Elektrik dan BOK Perahu Motor, dengan melalui survei penggunaan masing-masing kendaraan dan harga kendaraan serta suku cadang di daerah studi, yaitu sebagai berikut:

a. Komponen BOK Sepeda Motor elektrik:

1) $Y(E)=$ Biaya Konsumsi Elektrik, Kwh.

2) $Y(M)=$ Upah Mekanik, jam

3) $\mathrm{Y}(\mathrm{T})=$ keausan ban

4) $Y(B)=$ penggantian batere

5) $Y(P)=$ Penyusutan Kendaraan

b. Komponen BOK Perahu Motor (20 PK.)

analysis) suatu proyek mengikuti metodologi konvensional discounted cash flow dalam menghitung parameterparameter kelayakan proyek. Cara ini dilakukan untuk mendapatkan rencana mana yang paling baik dan dapat dipertanggungjawabkan mengingat masalah keterbatasan sumber daya (R.E.B. Tjokroadirejo, 1990). Pembangunan jalan baru dimaksudkan untuk mengurangi biaya operasi kendaraan disamping keuntungan lain yang tidak bisa dinilai, non quantifiable benefits (Budi Hartarto Susilo, 2017). Analisis kelayakan ekonomi melibatkan empat parameter penilaian yang digunakan, yaitu BOK sepeda motor dan BOK motor perahu, NPV, BCR dan IRR.

1) $Y(E)=$ konsumsi BBM, liter $/ \mathrm{km}$

2) $Y(M)=$ upah mekanik, jam

3) $\mathrm{Y}(\mathrm{Mn})=$ manintenance/ pemeliharaan

4) $Y(P)=$ Penyusutan kendaraan

\section{Net Present Value (NPV)}

Analisis NPV dilakukan dengan menghitung jumlah arus tunai bersih berdiskonto (discount net cash flow) selama periode proyek. Nilai NPV merupakan gambaran jumlah keuntungan bersih investasi yang dinilai pada saat ini dengan memperhitungkan opportunity cost investasi. Suatu proyek dikatakan layak secara ekonomi, apabila NPV $\geq 0$ atau dengan kata lain tingkat keuntungan yang 
diperoleh minimal harus sama dengan opportunity cost dari modal yang diinvestasikan. Persamaan perhitungan NPV sebagai berikut:

$$
N P V=\sum_{t=0}^{R_{t}} \frac{R_{t}}{(1+i)^{t}}-\sum_{t=0}^{t} \frac{C_{t}}{(1+i)^{t}}
$$

$\mathrm{Rt}=$ pendapatan pada tahun ke $\mathrm{t}$

$\mathrm{Ct}=$ biaya pada tahun ke $\mathrm{t}$

$\mathrm{i}=$ suku bunga umum yang berlaku

$\mathrm{t}=$ waktu (tahun)

\section{Benefit Cost Ratio (BCR)}

Analisis BCR dilakukan dengan menghitung perbandingan antara jumlah present value (nilai sekarang) dari arus tunai penerimaan (benefit) dengan nilai sekarang dari arus tunai biaya (cost). Untuk mencapai kelayakan ekonomi, suatu proyek harus mempunyai nilai $\mathrm{B} / \mathrm{C} \geq 1$. Persamaan perhitungan BCR:

$$
B C R=\frac{P V_{\text {benefit }}}{P V_{\text {Cost }}}
$$

$\mathrm{PV}$ benefits $=$ nilai sekarang atas keuntungan $\mathrm{PV}$ costs = nilai sekarang atas biaya

\section{Internal Rate of Return (IRR)}

Analisis IRR menunjukkan gambaran besarnya tingkat manfaat yang diperoleh dari suatu investasi dan pembiayaan proyek. Pada nilai NPV $=0$, maka nilai IRR akan sama dengan nilai discount factor.
Dengan demikian, suatu proyek dikatakan layak jika nilai IRR $\geq$ nilai discount factor. Jika nilai NPV memberikan gambaran tentang keuntungan bersih absolut suatu investasi, maka IRR mencerminkan efisiensi suatu investasi dan pembiayaan proyek. Dalam analisis IRR, pendekatan yang dilakukan didasarkan pada cash flow manfaat langsung dan tidak langsung dari adanya suatu proyek dengan cash flow investasi beserta pembiayaannya, mulai dari pekerjaan perencanaan (detail desain), pelaksanaan konstruksi, supervisi, eskalasi harga (khusus untuk proyek tahun jamak), sampai dengan biaya operasi pemeliharaan. Nilai yang muncul dari hasil analisis IRR ini memproyeksikan kelayakan suatu proyek dan besaran manfaat proyek bagi masyarakat baik secara langsung maupun tidak langsung sebagai bagian dari penilaian aspek ekonomi nasional dan regional. Persamaan perhitungan IRR ditunjukkan sebagai berikut.

$$
I R R=i_{1} \frac{N P V_{1}}{N P V_{1}-N P V_{2}}\left(i_{2}-i_{1}\right)
$$

$\mathrm{i}_{1}=$ tingkat diskonto yang menghasilkan $\mathrm{NPV+}$

$\mathrm{i}_{2}=$ tingkat diskonto yang menghasilkan NPV-

$\mathrm{NPV}_{1}=$ Net Present Value bernilai positif $\mathrm{NPV}_{2}=$ Net Present Value bernilai negatif Bagan alir dan parameter dalam analisis ekonomi dapat dilihat pada Gambar 1. 


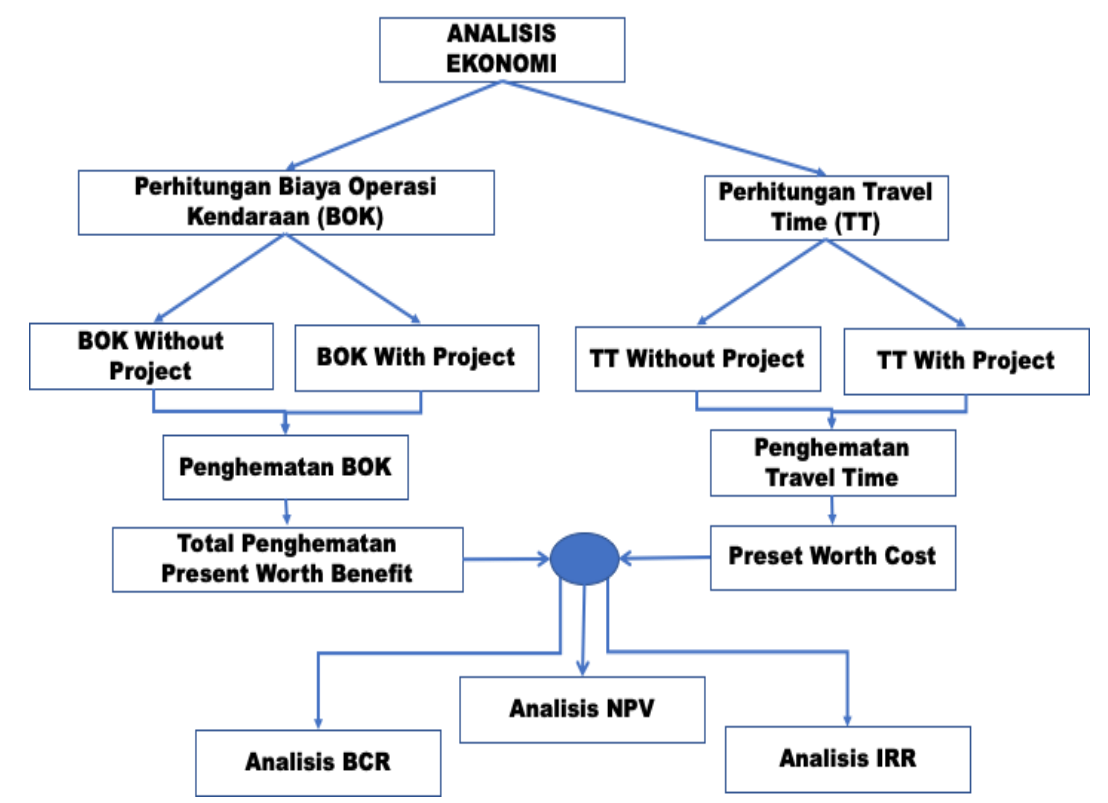

Gambar 1. Bagan alir dan parameter dalam analisis ekonomi

\section{Hasil dan Pembahasan}

Perhitungan BOK sepeda motor elektrik dan perahu motor berdasarkan pada hasil survei di lapangan mengenai penggunaan harian kendaraan dan besaran harga satuan setempat.

\section{Analisis dan Perhitungan BOK Sepeda Motor Elektrik}

a. Biaya tidak tetap

1) Konsumsi Energi Listrik

2) Pemeliharaan Jasa Kerja Mekanik

3) Konsumsi Ban

4) Pemeliharaan dan Suku Cadang

b. Biaya tetap

1) Depresiasi Kendaraan

2) Bunga Bank, bunga bank resmi ditetapkan oleh Bank Sentral untuk uang yang dipinjam darinya oleh bank komersial (Robbet L. Mitchell, 1980).

3) Asuransi

c. Harga satuan untuk Golongan kendaraan yang digunakan dalam perhitungan:

1) Harga Listrik per-Kwh= Rp.11.000

2) Upah Mekanik (jam)= Rp.50.000
3) Harga ban sepeda motor depan belakang= Rp. 400.000

4) Harga Batere Pengganti 1 unit= Rp. 2.000.000

5) Harga rata-rata 1 unit Sepeda Motor $=$ Rp. 15.000 .000

d. Kecepatan rata-rata dan jarak tempuh

1) Kecepatan rata-rata: $20 \mathrm{~km} / \mathrm{Jam}$

2) Setiap hari menempuh jarak: $30 \mathrm{~km}$

e. Perhitungan BOK

1) $Y(E)=$ Biaya Konsumsi Listrik, Rp. Kwh/1000 km

2) $Y(M)=$ upah mekanik, jam

3) $\mathrm{Y}(\mathrm{T})=$ Biaya Ban, keausan 1 ban tiap-tiap $1.000 \mathrm{~km}$

4) $Y(B:)=$ Biaya Batere, penggantian setiap $1.000 \mathrm{~km}$

5) $Y(P:)=$ Penyusutan kendaraan,

6) Perhitungan BOK per $1.000 \mathrm{~km}$ :

a) Biaya Energi $Y(E)$ :

- biaya listrik untuk menempuh $60 \mathrm{~km}=1,6$ kwh, $1 \mathrm{~km}=1,6 / 60=0,03$ kwh, $1 \mathrm{Kwh}=$ Rp. 11.000

- 1 hari $30 \mathrm{~km}=0,03 \times 30=$ $0,9 \mathrm{Kwh}$, 
- 1 hari $=0,9 \times 11.000=$ Rp. 9.900

- $1000 \mathrm{~km}=1000 \times 0,03$ $\mathrm{x} 11.000=$ Rp. 330.000,-

- $1 \mathrm{th}=30 \mathrm{~km} /$ hari $\times 300$ hari $=9000 \mathrm{~km}$

- $\quad \mathrm{Y}(\mathrm{E})=\mathrm{Rp} .330 .000 \mathrm{x}$ $9000 / 1000=R p .2 .970 .000$

b) Biaya Mekanik Y(M)

- Perlu perbaikan setiap menempuh $1.000 \mathrm{~km}$, waktu perbaikan 2 jam

- Biaya mekanik per jam Rp. 50.000,-

- Biaya per $1000 \mathrm{~km}=$ $2 \times 50.000=$ Rp. 100.000

- $\mathrm{Y}(\mathrm{M})=9000 / 1000 \times \mathrm{Rp}$. 100.000,- = Rp. 900.000,-

c) Biaya Ban $\mathrm{Y}(\mathrm{T})$

- Penggantian ban setiap $1000 \mathrm{~km}$

- Harga Ban depan + belakang Rp. 400.000

- $1000 \mathrm{~km}=$ Rp. 400.000,-

- $\mathrm{Y}(\mathrm{T})=9000 / 1000 \times \mathrm{Rp}$. $400.000=$ Rp. 3.600 .000

d) Biaya batere $Y(B)$

- Setiap $2.000 \mathrm{~km}$ ganti 1 unit batere

- harga 1 unit batere Rp. 2000.000

- $\quad$ Sehingga $1.000 \mathrm{~km}=1$ juta

- $\mathrm{Y}(\mathrm{B})=9000 / 1000 \times \mathrm{Rp}$. $1.000 .000=$ Rp. 9.000 .000

e) Biaya Penyusutan linier selama 5 th (habis) $\mathrm{Y}(\mathrm{P})=1 / 5 \times$ Rp. 15 juta $=$ Rp. 3.000.000/tahun.

f) BOK total 1 unit sepeda motor elektrik per tahun $=\mathrm{Y}(\mathrm{E})+$ $\mathrm{Y}(\mathrm{M})+\mathrm{Y}(\mathrm{T})+\mathrm{Y}(\mathrm{B})+\mathrm{Y}(\mathrm{P})=\mathrm{Rp}$. 19.470.000,-
Analisis dan Perhitungan BOK Perahu Motor

a. Biaya tidak tetap

1) Konsumsi BBM (Bensin)

2) Biaya Mekanik

3) Pemeliharaan dan Suku Cadang

b. Biaya tetap

1) Depresiasi Kendaraan

2) Bunga Bank

3) Asuransi

c. Harga satuan untuk Golongan kendaraan yang digunakan dalam perhitungan:
1) Harga Bensin per-liter= Rp.15.000
2) Upah Mekanik (jam) = Rp. 50.000
3) Biaya permeliharaan dan perbaikan $=$ Rp. 2.000 .000
4) Harga rata-rata 1 unit Perahu Motor $=$ Rp. 30.000 .000

d. Kecepatan rata-rata dan jarak tempuh

1) Kecepatan rata-rata: $16 \mathrm{~km} / \mathrm{Jam}$

2) Setiap hari menempuh jarak: $30 \mathrm{~km}$

e. Perhitungan BOK

1) $\mathrm{Y}(\mathrm{E})=$ Konsumsi bensin, $\mathrm{ltr} / \mathrm{km}$

2) $Y(M)=$ upah mekanik, jam

3) $Y(M n)=$ biaya perbaikan dan pemeliharaan

4) $Y(P)=$ Penyusutan kendaraan, dihitung dari harga kendaraan

f. Perhitungan BOK per $1.000 \mathrm{~km}$ :

1) Biaya Energi (BBM=Bensin) $Y(E)$

a) perahu motor, $\operatorname{mesin} 20 \mathrm{pk}=10$ $\mathrm{lt} / \mathrm{jam}$ dengan kec rata-rata= $20 \mathrm{~km} / \mathrm{jam}$

b) konsumsi bensin $=10 \mathrm{lt} / \mathrm{jam}: 20$ $\mathrm{km} / \mathrm{jam}=0,5 \mathrm{lt} / \mathrm{km}$

c) Harga BBM = Rp. $15.000 / \mathrm{lt}$

d) $1000 \mathrm{~km}=15.000 \times 0,5 \times 1000=\mathrm{Rp}$. 7.500.000,-

e) 1 hari $=30 \mathrm{~km}$

f) $Y(E)=(30 \mathrm{~km} x 300$ hari $) / 1000 \times \mathrm{Rp}$. $7.500 .000=$ Rp.67.500.000,- 
2) Biaya Mekanik
a) Perlu perbaikan setiap menempuh $1.000 \mathrm{~km}$, waktu perbaikan 2 jam
b) Biaya mekanik per jam Rp. 50.000,-
c) $1000 \mathrm{~km}=2 \mathrm{x} 50.000=\mathrm{Rp}$. 100.000
d) $Y(M)=9000 / 1000 \quad x \quad R p$. $100.000=$ Rp. 900.000,-

3) Biaya maintenance

Biaya perbaikan dan pemeliharaan perahu setiap $1.000 \mathrm{~km}=\mathrm{Rp}$. 2.000 .000

$\mathrm{Y}(\mathrm{Mn})=9000 / 1000 \mathrm{x}$ Rp. $2.000 .000=$ Rp. 18.000 .000

4) Biaya Penyusutan (5 tahun linier) harga rata-rata 1 unit perahu motor lengkap $=$ Rp. 30.000 .000 $\mathrm{Y}(\mathrm{B})=1 / 5 \quad \mathrm{x} \quad \mathrm{Rp} \cdot 30.000 .000=\mathrm{Rp}$. 6.000 .000

5) BOK Perahu Motor per tahun $=Y(E)$ $+Y(M)+Y(M n)+Y(P)=R p$.

32.400.000,-

\section{Perhitungan Penghematan BOK}

Untuk mendapatkan penghematan BOK diperoleh dari hasil perhitungan selisih nilai penghematan BOK with Project dengan BOK without Project Berdasarkan umur rencana selama 23 tahun. Dari perhitungan, diperoleh nilai total penghematan BOK sebesar Rp.252.809.551.559. Adapun perhitungan secara rinci disajikan pada Tabel 3 berikut ini

Tabel 3. Penghematan BOK

\begin{tabular}{|c|c|c|c|c|}
\hline \multirow{2}{*}{ Tahun } & \multirow{2}{*}{$\mathrm{n}$} & BOK Without Project (Rp.) & BOK With Project (Rp.) & \multirow{2}{*}{ Penghematan BOK (Rp.) } \\
\hline & & SEPEDA MOTOR ELEKTRIK & PERAHU MOTOR & \\
\hline 2019 & 0 & $11,057,791,800$ & $18,401,256,000$ & $7,343,464,200$ \\
\hline 2020 & 1 & $11,389,525,554$ & $18,953,293,680$ & $7,563,768,126$ \\
\hline 2021 & 2 & $11,731,211,321$ & $19,521,892,490$ & $7,790,681,170$ \\
\hline 2022 & 3 & $12,083,147,660$ & $20,107,549,265$ & $8,024,401,605$ \\
\hline 2023 & 4 & $12,445,642,090$ & $20,710,775,743$ & $8,265,133,653$ \\
\hline 2024 & 5 & $12,819,011,353$ & $21,332,099,015$ & $8,513,087,663$ \\
\hline 2025 & 6 & $13,203,581,693$ & $21,972,061,986$ & $8,768,480,292$ \\
\hline 2026 & 7 & $13,599,689,144$ & $22,631,223,845$ & $9,031,534,701$ \\
\hline 2027 & 8 & $14,007,679,818$ & $23,310,160,561$ & $9,302,480,742$ \\
\hline 2028 & 9 & $14,427,910,213$ & $24,009,465,378$ & $9,581,555,165$ \\
\hline 2029 & 10 & $14,860,747,519$ & $24,729,749,339$ & $9,869,001,820$ \\
\hline 2030 & 11 & $15,306,569,945$ & $25,471,641,819$ & $10,165,071,874$ \\
\hline 2031 & 12 & $15,765,767,043$ & $26,235,791,074$ & $10,470,024,030$ \\
\hline 2032 & 13 & $16,238,740,055$ & $27,022,864,806$ & $10,784,124,751$ \\
\hline 2033 & 14 & $16,725,902,256$ & $27,833,550,750$ & $11,107,648,494$ \\
\hline 2034 & 15 & $17,227,679,324$ & $28,668,557,273$ & $11,440,877,949$ \\
\hline 2035 & 16 & $17,744,509,704$ & $29,528,613,991$ & $11,784,104,287$ \\
\hline 2036 & 17 & $18,276,844,995$ & $30,414,472,410$ & $12,137,627,416$ \\
\hline 2037 & 18 & $18,825,150,345$ & $31,326,906,583$ & $12,501,756,238$ \\
\hline 2038 & 19 & $19,389,904,855$ & $32,266,713,780$ & $12,876,808,925$ \\
\hline 2039 & 20 & $19,971,602,001$ & $33,234,715,194$ & $13,263,113,193$ \\
\hline 2040 & 21 & $20,570,750,061$ & $34,231,756,649$ & $13,661,006,589$ \\
\hline 2041 & 22 & $21,187,872,562$ & $35,258,709,349$ & $14,070,836,786$ \\
\hline 2042 & 23 & $21,823,508,739$ & $36,316,470,629$ & $14,492,961,890$ \\
\hline \multicolumn{4}{|c|}{ Total } & $252,809,551,559$ \\
\hline
\end{tabular}




\section{Biaya Pembangunan dan Pemeliharaan}

a. Biaya Pembangunan Jalan

Hasil perhitungan biaya pembangunan jalan:

1) Biaya pembangunan jalan layang per $\mathrm{km}$ dengan lebar jalan $4 \mathrm{~m}=$ Rp.21.000.000.000;

2) Panjang jalan $3 \mathrm{~km}$

3) Biaya total pembangunan = Rp.21.000.000.000 x $3=$ Rp.63.000.000.000,- b. Hasil perhitungan biaya pemeliharaan

1) Biaya pemeliharaan tahunan per $\mathrm{km}=$ Rp.25.000.000,-

2) Biaya pemeliharaan jalan per tahun $=$ Rp. 900.000.000,-

3) Biaya pemeliharaan 5 tahunan per $\mathrm{km}=$ Rp.500.000.000,-

4) Biaya total pemeliharaan = Rp.50.419.883.758,-

Perhitungan biaya pemeliharaan disajikan pada Tabel 4 berikut ini

Tabel 4. Perhitungan Biaya Pemeliharaan Jalan

\begin{tabular}{|c|c|c|c|c|}
\hline $\mathrm{n}$ & Tahun & $\begin{array}{c}\text { Biaya } \\
\text { Pemeliharaan per } \\
\text { tahun }\end{array}$ & $\begin{array}{c}\text { Biaya } \\
\text { Pemeliharaan } \\
\text { per } 5 \text { tahun }\end{array}$ & $\begin{array}{c}\text { Total Biaya } \\
\text { pemeliharaan }\end{array}$ \\
\hline 0 & 2018 & - & & - \\
\hline 1 & 2019 & $900,000,000$ & & $900,000,000$ \\
\hline 2 & 2020 & $949,500,000$ & & $949,500,000$ \\
\hline 3 & 2021 & $1,001,722,500$ & & $1,001,722,500$ \\
\hline 4 & 2022 & $1,056,817,238$ & & $1,056,817,238$ \\
\hline 5 & 2023 & $1,114,942,186$ & $1,869,272,906$ & $2,984,215,092$ \\
\hline 6 & 2024 & $1,176,264,006$ & & $1,176,264,006$ \\
\hline 7 & 2025 & $1,240,958,526$ & & $1,240,958,526$ \\
\hline 8 & 2026 & $1,309,211,245$ & & $1,309,211,245$ \\
\hline 9 & 2027 & $1,381,217,863$ & & $1,381,217,863$ \\
\hline 10 & 2028 & $1,457,184,846$ & $2,329,454,133$ & $3,786,638,979$ \\
\hline 11 & 2029 & $1,537,330,013$ & & $1,537,330,013$ \\
\hline 12 & 2030 & $1,621,883,163$ & & $1,621,883,163$ \\
\hline 13 & 2031 & $1,711,086,737$ & & $1,711,086,737$ \\
\hline 14 & 2032 & $1,805,196,508$ & & $1,805,196,508$ \\
\hline 15 & 2033 & $1,904,482,316$ & $2,902,923,665$ & $4,807,405,980$ \\
\hline 16 & 2034 & $2,009,228,843$ & & $2,009,228,843$ \\
\hline 17 & 2035 & $2,119,736,429$ & & $2,119,736,429$ \\
\hline 18 & 2036 & $2,236,321,933$ & & $2,236,321,933$ \\
\hline 19 & 2037 & $2,359,319,639$ & & $2,359,319,639$ \\
\hline 20 & 2038 & $2,489,082,219$ & $3,617,571,037$ & $6,106,653,257$ \\
\hline 21 & 2039 & $2,625,981,742$ & & $2,625,981,742$ \\
\hline 22 & 2040 & $2,770,410,737$ & & $2,770,410,737$ \\
\hline 23 & 2041 & $2,922,783,328$ & & $2,922,783,328$ \\
\hline \multicolumn{2}{|c|}{ Total } & $39,700,662,017$ & $10,719,221,741$ & $50,419,883,758$ \\
\hline
\end{tabular}




\section{Perhitungan BCR, NPV dan IRR}

Dari hasil perhitungan dibawah ini diperoleh hasil sebagai berikut:

a. $\quad \mathrm{BCR}=(\mathrm{K}+\mathrm{C}) / \mathrm{B}=\mathrm{Rp} \cdot 238,316,589,669$ /Rp.113.419.883.758 = 2,101 (Tabel 5)

b. $\quad \mathrm{NPV}=\mathrm{Rp} .23 .015 .691 .841,-$ c. $\quad$ IRR $=10,61 \%$

Untuk perhitungan secara rinci disajikan pada tabel-tabel berikut ini:

- Perhitungan BCR pada Tabel 5.

- Perhitungan NPV pada Tabel 6.

- $\quad$ Perhitungan IRR pada Tabel 7

Tabel 5. Perhitungan Benefit Cost Ratio (BCR)

\begin{tabular}{|c|c|c|c|c|}
\hline \multirow{2}{*}{ Tahun } & \multirow{2}{*}{$\mathrm{n}$} & Capital & Cost & Benefit \\
\hline & & K & $\mathrm{C}$ & B \\
\hline 2018 & 0 & $25,200,000,000$ & - & \\
\hline 2019 & 1 & $37,800,000,000$ & $900,000,000$ & $7,343,464,200$ \\
\hline 2020 & 2 & & $949,500,000$ & $7,563,768,126$ \\
\hline 2021 & 3 & & $1,001,722,500$ & $7,790,681,170$ \\
\hline 2022 & 4 & & $1,056,817,238$ & $8,024,401,605$ \\
\hline 2023 & 5 & & $2,984,215,092$ & $8,265,133,653$ \\
\hline 2024 & 6 & & $1,176,264,006$ & $8,513,087,663$ \\
\hline 2025 & 7 & & $1,240,958,526$ & $8,768,480,292$ \\
\hline 2026 & 8 & & $1,309,211,245$ & $9,031,534,701$ \\
\hline 2027 & 9 & & $1,381,217,863$ & $9,302,480,742$ \\
\hline 2028 & 10 & & $3,786,638,979$ & $9,581,555,165$ \\
\hline 2029 & 11 & & $1,537,330,013$ & $9,869,001,820$ \\
\hline 2030 & 12 & & $1,621,883,163$ & $10,165,071,874$ \\
\hline 2031 & 13 & & $1,711,086,737$ & $10,470,024,030$ \\
\hline 2032 & 14 & & $1,805,196,508$ & $10,784,124,751$ \\
\hline 2033 & 15 & & $4,807,405,980$ & $11,107,648,494$ \\
\hline 2034 & 16 & & $2,009,228,843$ & $11,440,877,949$ \\
\hline 2035 & 17 & & $2,119,736,429$ & $11,784,104,287$ \\
\hline 2036 & 18 & & $2,236,321,933$ & $12,137,627,416$ \\
\hline 2037 & 19 & & $2,359,319,639$ & $12,501,756,238$ \\
\hline 2038 & 20 & & $6,106,653,257$ & $12,876,808,925$ \\
\hline 2039 & 21 & & $2,625,981,742$ & $13,263,113,193$ \\
\hline 2040 & 22 & & $2,770,410,737$ & $13,661,006,589$ \\
\hline 2041 & 23 & & $2,922,783,328$ & $14,070,836,786$ \\
\hline & & $63,000,000,000$ & $50,419,883,758$ & $238,316,589,669$ \\
\hline
\end{tabular}

Tabel 6. Perhitungan Net Present Value (NPV)

\begin{tabular}{|c|c|c|c|c|c|c|c|c|c|}
\hline \multirow[b]{2}{*}{ Tahun } & \multirow[b]{2}{*}{$\mathrm{n}$} & \multirow{2}{*}{$\begin{array}{c}\text { Capital } \\
\text { K }\end{array}$} & \multirow{2}{*}{$\begin{array}{c}\text { Cost } \\
\text { C }\end{array}$} & \multirow{2}{*}{$\begin{array}{c}\text { Benefit } \\
\text { B }\end{array}$} & \multirow{2}{*}{$\begin{array}{l}\text { disc. } \\
\text { Factor } \\
7 \%\end{array}$} & \multicolumn{4}{|c|}{ Discounted/ NPV } \\
\hline & & & & & & K & $\mathrm{C}$ & B & $\begin{array}{c}\text { Net } \\
\text { Benefit } \\
\text { (NB) }\end{array}$ \\
\hline 2018 & 0 & $\begin{array}{c}25,200,00 \\
0,000\end{array}$ & 0 & - & 1.000 & $\begin{array}{c}25,200,0 \\
00,000\end{array}$ & 0 & 0 & $\begin{array}{c}(25,200, \\
000,000 \\
)\end{array}$ \\
\hline
\end{tabular}




\begin{tabular}{|c|c|c|c|c|c|c|c|c|c|}
\hline \multirow[b]{2}{*}{ Tahun } & \multirow[b]{2}{*}{$\mathrm{n}$} & \multirow{2}{*}{$\begin{array}{c}\text { Capital } \\
\mathrm{K}\end{array}$} & \multirow{2}{*}{$\begin{array}{c}\text { Cost } \\
\mathrm{C}\end{array}$} & \multirow{2}{*}{$\begin{array}{c}\text { Benefit } \\
\text { B }\end{array}$} & \multirow{2}{*}{$\begin{array}{l}\text { disc. } \\
\text { Factor } \\
7 \%\end{array}$} & \multicolumn{4}{|c|}{ Discounted/ NPV } \\
\hline & & & & & & K & $\mathrm{C}$ & B & $\begin{array}{c}\text { Net } \\
\text { Benefit } \\
\text { (NB) }\end{array}$ \\
\hline 2019 & 1 & $\begin{array}{c}37,800,00 \\
0,000\end{array}$ & $\begin{array}{c}900,000,0 \\
00\end{array}$ & $\begin{array}{c}7,343,464,2 \\
00\end{array}$ & 0.935 & $\begin{array}{c}37,800,0 \\
00,000\end{array}$ & $\begin{array}{c}841,121 \\
495\end{array}$ & $\begin{array}{c}6,863,05 \\
0,654\end{array}$ & $\begin{array}{c}31,778, \\
070,841 \\
)\end{array}$ \\
\hline 2020 & 2 & & $\begin{array}{c}949,500,0 \\
00 \\
\end{array}$ & $\begin{array}{c}7,563,768,1 \\
26 \\
\end{array}$ & 0.873 & - & $\begin{array}{c}829,330, \\
072 \\
\end{array}$ & $\begin{array}{c}6,606,48 \\
8,013 \\
\end{array}$ & $\begin{array}{c}5,777,15 \\
7,940 \\
\end{array}$ \\
\hline 2021 & 3 & & $\begin{array}{c}1,001,722 \\
, 500\end{array}$ & $\begin{array}{c}7,790,681,1 \\
70 \\
\end{array}$ & 0.816 & - & $\begin{array}{c}817,703 \\
950 \\
\end{array}$ & $\begin{array}{c}6,359,51 \\
6,498 \\
\end{array}$ & $\begin{array}{c}5,541,81 \\
2,548\end{array}$ \\
\hline 2022 & 4 & & $\begin{array}{c}1,056,817 \\
, 238\end{array}$ & $\begin{array}{c}8,024,401,6 \\
05\end{array}$ & 0.763 & - & $\begin{array}{c}806,240 \\
810\end{array}$ & $\begin{array}{c}6,121,77 \\
7,564\end{array}$ & $\begin{array}{c}5,315,53 \\
6,753\end{array}$ \\
\hline 2023 & 5 & & $\begin{array}{c}2,984,215 \\
, 092\end{array}$ & $\begin{array}{c}8,265,133,6 \\
53\end{array}$ & 0.713 & - & $\begin{array}{c}2,127,70 \\
4,117\end{array}$ & $\begin{array}{c}5,892,92 \\
6,066\end{array}$ & $\begin{array}{c}3,765,22 \\
1,949\end{array}$ \\
\hline 2024 & 6 & & $\begin{array}{c}1,176,264 \\
, 006\end{array}$ & $\begin{array}{c}8,513,087,6 \\
63\end{array}$ & 0.666 & - & $\begin{array}{c}783,794 \\
373\end{array}$ & $\begin{array}{c}5,672,62 \\
9,765\end{array}$ & $\begin{array}{c}4,888,83 \\
5,391\end{array}$ \\
\hline 2025 & 7 & & $\begin{array}{c}1,240,958 \\
, 526\end{array}$ & $\begin{array}{c}8,768,480,2 \\
92\end{array}$ & 0.623 & - & $\begin{array}{c}772,806 \\
602\end{array}$ & $\begin{array}{c}5,460,56 \\
8,839\end{array}$ & $\begin{array}{c}4,687,76 \\
2,237\end{array}$ \\
\hline 2026 & 8 & & $\begin{array}{c}1,309,211 \\
, 245\end{array}$ & $\begin{array}{c}9,031,534,7 \\
01\end{array}$ & 0.582 & - & $\begin{array}{c}761,972 \\
864\end{array}$ & $\begin{array}{c}5,256,43 \\
5,424\end{array}$ & $\begin{array}{c}4,494,46 \\
2,560\end{array}$ \\
\hline 2027 & 9 & & $\begin{array}{c}1,381,217 \\
, 863\end{array}$ & $\begin{array}{c}9,302,480,7 \\
42\end{array}$ & 0.544 & - & $\begin{array}{c}751,291 \\
002\end{array}$ & $\begin{array}{c}5,059,93 \\
3,165\end{array}$ & $\begin{array}{c}4,308,64 \\
2,164\end{array}$ \\
\hline 2028 & 10 & & $\begin{array}{c}3,786,638 \\
, 979\end{array}$ & $\begin{array}{c}9,581,555,1 \\
65\end{array}$ & 0.508 & - & $\begin{array}{c}1,924,93 \\
5,244\end{array}$ & $\begin{array}{c}4,870,77 \\
6,785\end{array}$ & $\begin{array}{c}2,945,84 \\
1,541\end{array}$ \\
\hline 2029 & 11 & & $\begin{array}{c}1,537,330 \\
, 013\end{array}$ & $\begin{array}{c}9,869,001,8 \\
20\end{array}$ & 0.475 & - & $\begin{array}{c}730,374 \\
415\end{array}$ & $\begin{array}{c}4,688,69 \\
1,672\end{array}$ & $\begin{array}{c}3,958,31 \\
7,257\end{array}$ \\
\hline 2030 & 12 & & $\begin{array}{c}1,621,883 \\
, 163\end{array}$ & $\begin{array}{c}10,165,071 \\
874\end{array}$ & 0.444 & - & $\begin{array}{c}720,135 \\
521\end{array}$ & $\begin{array}{c}4,513,41 \\
3,479\end{array}$ & $\begin{array}{c}3,793,27 \\
7,958\end{array}$ \\
\hline 2031 & 13 & & $\begin{array}{c}1,711,086 \\
, 737\end{array}$ & $\begin{array}{c}10,470,024 \\
030\end{array}$ & 0.415 & - & $\begin{array}{c}710,040 \\
163\end{array}$ & $\begin{array}{c}4,344,68 \\
7,741\end{array}$ & $\begin{array}{c}3,634,64 \\
7,578\end{array}$ \\
\hline 2032 & 14 & & $\begin{array}{c}1,805,196 \\
, 508\end{array}$ & $\begin{array}{c}10,784,124 \\
751\end{array}$ & 0.388 & - & $\begin{array}{c}700,086 \\
329\end{array}$ & $\begin{array}{c}4,182,26 \\
9,508\end{array}$ & $\begin{array}{c}3,482,18 \\
3,179\end{array}$ \\
\hline 2033 & 15 & & $\begin{array}{c}4,807,405 \\
, 980\end{array}$ & $\begin{array}{c}11,107,648 \\
494\end{array}$ & 0.362 & - & $\begin{array}{c}1,742,42 \\
5,162\end{array}$ & $\begin{array}{c}4,025,92 \\
2,984\end{array}$ & $\begin{array}{c}2,283,49 \\
7,822\end{array}$ \\
\hline 2034 & 16 & & $\begin{array}{c}2,009,228 \\
, 843\end{array}$ & $\begin{array}{c}\text { 11,440,877 } \\
949\end{array}$ & 0.339 & - & $\begin{array}{c}\text { 680,595, } \\
324\end{array}$ & $\begin{array}{c}3,875,42 \\
1,190\end{array}$ & $\begin{array}{c}3,194,82 \\
5,866\end{array}$ \\
\hline 2035 & 17 & & $\begin{array}{c}2,119,736 \\
, 429\end{array}$ & $\begin{array}{c}11,784,104 \\
287\end{array}$ & 0.317 & - & $\begin{array}{c}671,054 \\
268\end{array}$ & $\begin{array}{c}3,730,54 \\
5,632\end{array}$ & $\begin{array}{c}3,059,49 \\
1,364\end{array}$ \\
\hline 2036 & 18 & & $\begin{array}{c}2,236,321 \\
, 933\end{array}$ & $\begin{array}{c}\text { 12,137,627 } \\
416\end{array}$ & 0.296 & - & $\begin{array}{c}661,646, \\
965\end{array}$ & $\begin{array}{c}3,591,08 \\
5,982\end{array}$ & $\begin{array}{c}2,929,43 \\
9,017\end{array}$ \\
\hline 2037 & 19 & & $\begin{array}{c}2,359,319 \\
, 639\end{array}$ & $\begin{array}{c}12,501,756 \\
238\end{array}$ & 0.277 & - & $\begin{array}{c}652,371 \\
541\end{array}$ & $\begin{array}{c}3,456,83 \\
9,777\end{array}$ & $\begin{array}{c}2,804,46 \\
8,237\end{array}$ \\
\hline 2038 & 20 & & $\begin{array}{c}6,106,653 \\
, 257\end{array}$ & $\begin{array}{c}12,876,808 \\
925\end{array}$ & 0.258 & - & $\begin{array}{c}1,578,07 \\
5,245\end{array}$ & $\begin{array}{c}3,327,61 \\
2,122\end{array}$ & $\begin{array}{c}1,749,53 \\
6,877\end{array}$ \\
\hline 2039 & 21 & & $\begin{array}{c}2,625,981 \\
, 742\end{array}$ & $\begin{array}{c}13,263,113 \\
193\end{array}$ & 0.242 & - & $\begin{array}{c}634,208 \\
956\end{array}$ & $\begin{array}{c}3,203,21 \\
5,407\end{array}$ & $\begin{array}{c}2,569,00 \\
6,451\end{array}$ \\
\hline 2040 & 22 & & $\begin{array}{c}2,770,410 \\
, 737\end{array}$ & $\begin{array}{c}13,661,006 \\
589\end{array}$ & 0.226 & - & $\begin{array}{c}625,318 \\
176\end{array}$ & $\begin{array}{c}3,083,46 \\
9,037\end{array}$ & $\begin{array}{c}2,458,15 \\
0,860\end{array}$ \\
\hline 2041 & 23 & & $\begin{array}{c}2,922,783 \\
, 328\end{array}$ & $\begin{array}{c}14,070,836 \\
786\end{array}$ & 0.211 & - & $\begin{array}{c}616,552 \\
034\end{array}$ & $\begin{array}{c}2,968,19 \\
9,166\end{array}$ & $\begin{array}{c}2,351,64 \\
7,132\end{array}$ \\
\hline & & $\begin{array}{c}63,000,00 \\
0,000\end{array}$ & $\begin{array}{c}50,419,88 \\
3,758\end{array}$ & $\begin{array}{c}238,316,58 \\
9,669\end{array}$ & & & $\begin{array}{c}21,139,7 \\
84,631\end{array}$ & $\begin{array}{l}107,155, \\
476,471\end{array}$ & $\begin{array}{l}23,015, \\
691,841\end{array}$ \\
\hline
\end{tabular}


Tabel 7. Perhitungan IRR

\begin{tabular}{|c|c|c|c|c|c|c|}
\hline \multirow{2}{*}{ Tahun } & \multirow{2}{*}{$\mathrm{n}$} & \multirow{2}{*}{$\begin{array}{c}\text { disc. } \\
\text { Factor } \\
10,61 \%\end{array}$} & \multicolumn{4}{|c|}{ Discounted/ NPV } \\
\hline & & & $\mathrm{K}$ & $\mathrm{C}$ & B & Net Benefit (NB) \\
\hline 2018 & 0 & 1 & $25,200,000,000$ & - & - & $(25,200,000,000)$ \\
\hline 2019 & 1 & 0.904 & $37,800,000,000$ & $813,684,363$ & $6,639,179,987$ & $(31,974,504,376)$ \\
\hline 2020 & 2 & 0.817 & - & $776,107,517$ & $6,182,514,273$ & $5,406,406,755$ \\
\hline 2021 & 3 & 0.739 & - & $740,266,012$ & $5,757,259,602$ & $5,016,993,590$ \\
\hline 2022 & 4 & 0.668 & - & $706,079,707$ & $5,361,255,416$ & $4,655,175,708$ \\
\hline 2023 & 5 & 0.604 & - & $1,802,591,939$ & $4,992,489,764$ & $3,189,897,825$ \\
\hline 2024 & 6 & 0.546 & - & $642,370,473$ & $4,649,089,087$ & $4,006,718,613$ \\
\hline 2025 & 7 & 0.494 & - & $612,705,093$ & $4,329,308,693$ & $3,716,603,600$ \\
\hline 2026 & 8 & 0.446 & - & $584,409,693$ & $4,031,523,899$ & $3,447,114,206$ \\
\hline 2027 & 9 & 0.404 & - & $557,421,006$ & $3,754,221,770$ & $3,196,800,764$ \\
\hline 2028 & 10 & 0.365 & - & $1,381,619,664$ & $3,495,993,439$ & $2,114,373,775$ \\
\hline 2029 & 11 & 0.330 & - & $507,125,175$ & $3,255,526,944$ & $2,748,401,769$ \\
\hline 2030 & 12 & 0.298 & - & $483,705,573$ & $3,031,600,565$ & $2,547,894,992$ \\
\hline 2031 & 13 & 0.270 & - & $461,367,513$ & $2,823,076,614$ & $2,361,709,101$ \\
\hline 2032 & 14 & 0.244 & - & $440,061,050$ & $2,628,895,661$ & $2,188,834,611$ \\
\hline 2033 & 15 & 0.220 & - & $1,059,528,654$ & $2,448,071,144$ & $1,388,542,490$ \\
\hline 2034 & 16 & 0.199 & - & $400,354,553$ & $2,279,684,361$ & $1,879,329,809$ \\
\hline 2035 & 17 & 0.180 & - & $381,865,736$ & $2,122,879,803$ & $1,741,014,067$ \\
\hline 2036 & 18 & 0.163 & - & $364,230,753$ & $1,976,860,803$ & $1,612,630,050$ \\
\hline 2037 & 19 & 0.147 & - & $347,410,173$ & $1,840,885,494$ & $1,493,475,321$ \\
\hline 2038 & 20 & 0.133 & - & $812,966,163$ & $1,714,263,036$ & $901,296,872$ \\
\hline 2039 & 21 & 0.120 & - & $316,063,519$ & $1,596,350,107$ & $1,280,286,588$ \\
\hline 2040 & 22 & 0.109 & - & $301,467,356$ & $1,486,547,637$ & $1,185,080,281$ \\
\hline 2041 & 23 & 0.098 & - & $287,545,259$ & $1,384,297,760$ & $1,096,752,501$ \\
\hline \multicolumn{2}{|c|}{ Total } & & $63,000,000,000$ & $\begin{array}{c}14,780,946,94 \\
7\end{array}$ & $\begin{array}{c}77,781,775,85 \\
8\end{array}$ & 828,911 \\
\hline
\end{tabular}

\section{Simpulan}

Evaluasi biaya dan manfaat ekonomi proyek ini, diperoleh hasil-hasil sebagai berikut:
a. $\mathrm{BCR}=2,101>1$
b. $\mathrm{NPV} \quad=$ Rp. 23.015.691.841, $-\geq 0$
c. IRR $=10,61 \%>6 \%$ (diatas bunga bank yang berlaku $=6 \%$ )

Sehingga dapat disimpulkan pembangunan jalan layang dengan permukaan jalan slab beton dengan lebar 4 meter, panjang $3 \mathrm{~km}$ di Distrik Agats, Kabupaten Asmat dinyatakan layak secara ekonomi.

\section{Daftar Pustaka}

Budi Hartarto Susilo (2017). Dasar-Dasar Rekayasa Transportasi Cetakan Kedua, Penerbit Universitas Trisakti, Jakarta.

Indonesia, Badan Pusat Statistik-BPS (Asmat dalam angka 2017-2018).

Keneth J. Burton (1993). Transport Economics, $2^{\text {nd }}$ Edition, Edward Elgar Publishing Limited, Gower House, Croft Road Aldershot Hants GUI 1 3HR, England. 
Peraturan Pemerintah Republik Indonesia Nomor 34 Tahun 2006 tentang Jalan, Pasal 40, yaitu: Ruang Milik Jalan.

R.E.B. Tjokroadiredjo (1990), Ekonomi Rekayasa Transport (Transport Engineering Economics) Semester II, Institut Teknologi Bandung.

Robert L. Mitchell (1980), Engineering Economics, John Wiley \& Sons Ltd. 